\title{
Sustainable Cities and Soil Quality of Green Spaces
}

\author{
L. Giuffré ${ }^{1}$, L. Marbán ${ }^{1}$, C.Vespasiano ${ }^{1}$, G. Moreno ${ }^{1}$, R.P. Rios ${ }^{1}$ \\ ${ }^{(1)}$ Departamento de Recursos Naturales y Ambiente, Facultad de Agronomía, Cátedra de Edafología, \\ Universidad de Buenos Aires, Argentina
}

\begin{abstract}
Livability in cities is linked to the optimization of the conditions of urban life related to the environment in which organisms develop, and green spaces guarantee much of the biodiversity in cities. Environmental Plan of Buenos Aires (Argentina) establishes the protection, regulation and control of levels of environmental and landscape quality of public space. Urban soils may be classified as Technosols, and should be handled carefully because it may contain toxic substances. The aim of this work is to study the quality of soils considering the analysis of fertility conditions, and the content of heavy metals in urban green spaces in Buenos Aires and surroundings, since the presence of these contaminants involves risk to the health of the community. Random sampling in 48 squares of the city of Buenos Aires was performed, with a composite sample for each green space. To evaluate fertility, actual pH, electrical conductivity in the saturation extract, Bray - extractable phosphorus, total organic carbon and total nitrogen were determined. The total content of the metals cadmium, chromium, copper, nickel, lead and zinc ( $\mathrm{Cd}, \mathrm{Cr}, \mathrm{Cu}, \mathrm{Ni}, \mathrm{Pb}$ and $\mathrm{Zn}$, respectively), was evaluated in extraction with aqua regia and ICP determination. The average and maximum values resulted acceptable for Argentina legislation. Metals that showed the highest values in the studied soils were Zn and Pb. Principal component analysis showed the association between the squares and the contents of heavy metals, which can serve as a guide for monitoring samples at successive times to ensure that there is no risk for the population.
\end{abstract}

Keywords: soil quality, community health, sustainable cities

\section{Introduction}

Cities are complex ecological systems dominated by humans. The human elements make them different from natural ecosystems in many ways. From an ecological perspective, urban ecosystems differ from natural ones in several respects: climate, soil, hydrology, species composition, population dynamics and flows of matter and energy (Alberti, 2008).Sustainable cities are still far from being a reality with today's technological advances, however it is interesting to investigate what are the points that increase the sustainability of a city: more green spaces to produce oxygen and take $\mathrm{CO}_{2}$, increased green spaces including green roofs on buildings to reduce heat island effect and reduce flooding by absorbing some of rainwater, efficient transport of food and energy, use of renewable energy, waste management. Several cities in the world have specialized in specific issues, but so far none applies all (Herrera Vegas, 2010).

According to Petrelli (2009) is quite easy to see the rural land as an economic and environmental resource, but the urban land is no exception to both conditions, since "the soil, plus an economic resource is a natural resource, scarce and non-renewable ", whether urban or rural, and " the city has an environmental value, such as collective cultural creation that is the subject of ongoing recreation" (Real Decreto Legislativo, 2008). The livability is related to the optimization of the conditions of urban life and living people and the ability to link between them and the environment in which organisms develop. Urban model that best fits the principle of urban efficiency and livability is the compact city in morphology, complex in its organization, metabolically efficient and socially cohesive. Indicators of complexity (diversity) show the maturity of the urban fabric and the richness of the economic, social and biological capital. The ecological urbanism adopts this model both for the transformation of existing tissues and the design of new urban developments (Rueda, 2012). Gambuzzi $(2009,2012)$ established that in a city there are socio-economic, cultural, territorial and environmental changes, which seem to act independently of the spaces, regardless that these spaces are ecospheres in which cities were formed. Any territory began as a landscape, and the landscape works as a system, in which each of the parties and actors should add for balance. If there is a fast-growing, urban lands are incorporated without the provision of infrastructure and services to the citizens, and also adding environmental problems: soil, water and atmosphere contamination, problems with the collection and treatment of solid waste and noise.

The European Commission (2004) established as a priority the re-use of urban resources, especially land, to avoid inefficient urban development (e.g. brownfields whose recovery may be difficult due to contamination). Sustainable planning of land use must meet the desires and needs of citizens. Developments of a city should include the necessary services, greenery, and employment opportunities, which are often excluded from economic development plans. PNUD (2013) proposed as a goal to achieve a better quality of life for people, comprehensively addressing issues that govern the formation of cities, looking for their integrated development as socially, environmentally and economically balanced. Cities are major consumers of energy and 
water as well as large generators of emissions to the atmosphere and water and also present soil contamination. Their way of relating to the natural environment has effects that must be resolved according to the necessary progress of the country, the good and the common interests of the inhabitants of each city and town center.The manipulation and disturbance to urban soils by various construction and restoration activities cause compaction of the surface, and affects the soil by reducing the ease of root penetration, decreasing the ready movement of water, and causing a reduction in its water-holding capacity. Compaction also reduces the movement of gases into and out of the soil, and reduces the total pore space and the mean pore size of the soil (Craul, 1992). Soil sealing in cities has drastic consequences as buildings and sealed soil surfaces store the sun's energy throughout the day and cool only slowly during the night. Sealed surfaces can therefore be up to $20^{\circ} \mathrm{C}$ warmer than unsealed ground or surfaces which are shaded by vegetation. Heat periods in cities result in the increased use of air conditioning units thereby creating additional emissions (IASS. 2013b).

In the city of Buenos Aires (Argentina), the Urban Environmental Plan (PUA, 2008), Article 4, postulated that the City develops the following features: integrated, polycentric, healthy, plural, and diverse, with plurality of activities and residential forms, combining the requirements of environmental quality of each. The Article 9 aims to increase recovery and improvement of public space and circulation, parks, squares and avenues and areas of asset quality to lead to vital functions such as find relaxation, comfort and socialization, ensuring all citizens the right to use, and giving identity to the different areas of the city .The Agenda 2030 fixed 17 new global Sustainable Development Goals that comprise economical, productive environmental and social issues at United Nations Headquarters in New York (25- 27 September 2015), to ensure protection of the planet ans its natural resources. They also resolved to create conditions for sustainable, inclusive and sustained economic growth (UN,2015). As an example, Georgi \& Dimitrou (2010) investigated how vegetation, mainly through evapotranspiration, affects the improvement of microclimatic conditions in urban areas and it examines the case for the city of Chania in Crete. The objectives of this study are to examine the bioclimatic role of green areas in urban sites as they affect the thermal comfort of residents.

Soils of green spaces combine the properties of natural soils with specific attributes of urban environments. Stroganova and Prokofieva (2000) studied in the Russian urban soils and proposed the central concept of Urbanozem. Urban soils may also be classified as Technosols, and should be handled carefully because it may contain toxic substances, as heavy metals (WRB, 2006).Urban green spaces supply to cities with ecosystem services ranging from maintenance of biodiversity to the regulation of urban climate. Pollution in cities as a form of pollutants includes chemicals, particulate matter and biological materials, which occur in the form of solid particles, liquid droplets or gases, the most affected by such detrimental contaminants are children, the elderly and people with respiratory problems Urban greening can reduce air pollutants directly when dust and smoke particles are trapped by vegetation (Atiqul Hak, 2011).Public space has a cultural dimension plus besides a functional or utilitarian dimension, as it represents the identity and values of the different communities. The urban environment has become supremely important with regard to human health and wellbeing. For centuries, urbanisation has caused relatively low level soil contamination, mainly by various wastes. However, from the time of the Industrial Revolution onwards, both the scale of urban development and the degree of soil contamination rapidly increased and involved an ever widening spectrum of contaminants (Meuser, 2010).

The extent of contaminated soil is best known in North America and Western Europe, where many countries have a legal framework to identify and deal with soil contamination. In contrast, developing countries tend to be less tightly regulated and the extent of urban soil contamination is less well known (IASS, 2013a).

With reference to contamination in the environment and the impact on human health, research on potentially harmful elements (PHEs) in the environmental, agricultural and life sciences is extensively increasing since the last decades, owing to the larger consciousness of general population of the risks induced by anthropic activities to human health. Environmental studies could make special reference to soil as one of the most vulnerable ecosystems, and a precious resource with limited resilience capacity.Current studies of PHEs in ecosystems have indicated that many industrial areas near urban agglomerates, major road systems (highways and national roads)act as sources, and at the same time sinks, of PHEs (particularly $\mathrm{Zn}, \mathrm{Cu}, \mathrm{Cd}$ ). In these areas, large amounts of metals are recycled or dispersed in the environment, posing severe concerns to human health (Bini and Bech, 2014). According to IASS (2013) prolonged exposure to low levels of metals, with contact by ingestion, inhalation or skin, can cause severe health problems: cancer, neurological damage, lower IQ (intelligence quotient), kidney disease, bone problems. Werkenthin et al (2014) presented a review analysing metals in soils at European roadsides. Highest median values of $\mathrm{Cr}, \mathrm{Cu}, \mathrm{Ni}, \mathrm{Pb}$, and $\mathrm{Zn}$ were determined in the top soil layer at the first $5 \mathrm{~m}$ beside the road. Generally, the influence of traffic on soil contamination decreased with increasing soil depth and distance to the road. Also, de Santiago-Martin et al (2015) reported that in recent decades, Mediterranean metropolitan areas have undergone rapid industrialisation and urbanisation, leading to an increase in trace metal contamination in soils and directly affecting public health. The bioavailable metal concentration may be increased by the action of soil organisms and/or changes in environmental conditions, thus 
highlighting the vulnerability of these soils. The aim of this work is to study the soil quality conditions related to fertility and contamination due to heavy metal content in soils of green spaces in Buenos Aires, Argentina.

\section{Materials And Methods}

Random sampling in 48 squares of the city of Buenos Aires was performed, with a composite sample for each green space, ( $3 \mathrm{sub}$-samples, 0-15 cm depth). The samples were air dried for 24 to 48 hours, and sieved by $2 \mathrm{~mm}$ metal sieve for general analysis, and plastic sieve $<0.5 \mathrm{~mm}$ for the analysis of heavy metals.Fertility and general properties: the routine analysis were: soil texture, soil actual $\mathrm{pH}$, electrical conductivity in the saturation extract , Bray - extractable phosphorus, total organic carbon and total nitrogen (Page , 1982). Heavy metals $\mathrm{Cu}, \mathrm{Ni}, \mathrm{Pb}, \mathrm{Zn}$, were evaluated using the technique of McGrath \& Cunliffe (1985). Soil samples were subjected to acid digestion with aqua regia $(3: 1 \mathrm{HCl}: \mathrm{HNO} 3)$ in Teflon containers in a 1:20 soil:solution. The aqua regia extracted metals were quantified by inductively coupled plasma atomic emission spectroscopy (ICPAES) on a Baird- 2070 ICP. To evaluate the effectiveness of the quantification a reference material Certipur ${ }^{\circledR}$. Solución IV for ICP was used. The data obtained were analyzed using descriptive statistics and multivariate analysis (Infostat, 2002).

\section{Results And Discussion}

Soils showed a great variability in texture: silt loam in 8 samples, loam in 11 samples, silty clay loam in 14 samples, and clay loam in the remaining 15 samples. As usually occurs when sampling urban soils, compaction was observed. The results for other variables are presented in Table 1.

Table 1: Physico-chemical and chemical variables

\begin{tabular}{|l|l|l|}
\hline Variable & Mean & Range \\
\hline $\mathrm{pH}$ & 7,22 & $6,02-8,22$ \\
\hline $\mathrm{CE}$ & 0,8 & $0,3-3,16$ \\
\hline $\mathrm{Ct} \%$ & 1,79 & $0,78-3,54$ \\
\hline P-Bray ppm & 21,45 & $5,12-80,25$ \\
\hline
\end{tabular}

Determinations showed normal values and low variability for $\mathrm{pH}$ and EC. Phosphorus presented high variability and low to good provision, consistent with Pouyat et al (2007) who found great variability in chemical variables of urban land. The contents of total carbon in soils were high with reference to those presented by other authors (Scheyer, 2000), this fact emphasizes the important role of some urban green spaces as carbon sinks, coinciding with exposed for Pouyat et al (2006) .

$\mathrm{Pb}$ and $\mathrm{Zn}$ presented the highest values in soil samples (Fig.1).

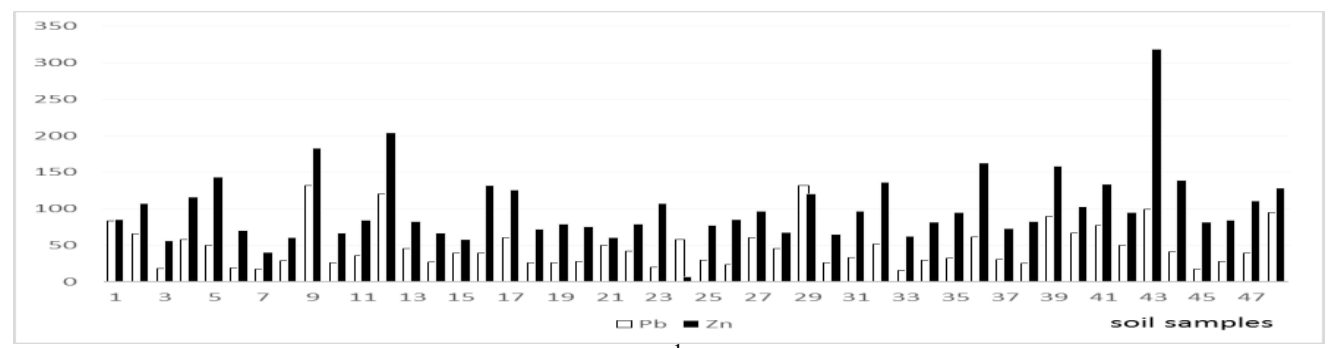

Figure 1: Heavy metals $\mathrm{Pb}$ and $\mathrm{Zn}\left(\mathrm{ug} \mathrm{g}^{-1}\right.$ soil) in soils of green spaces $(0-15 \mathrm{~cm})$.

The comparison of metal content to guide levels of argentine law is shown in Table 2.

Table 2: Descriptive statistics of the content of heavy metals in soils and their levels compared to Argentine soil quality guideline for agricultural soil, Law 24051, Regulatory Decree 831/1993.

\begin{tabular}{|l|l|l|l|l|l|}
\hline Metal & $\begin{array}{l}\text { Range } \\
\left(\mu \mathrm{g} \mathrm{g}^{-1} \text { suelo }\right)\end{array}$ & Mean & Standard deviation & Average value & Maximum value \\
\hline $\mathrm{Cu}$ & $12,6-84,3$ & 27,73 & 16,04 & acceptable & acceptable \\
\hline $\mathrm{Ni}$ & $3,5-16$ & 7,37 & 2,63 & acceptable & acceptable \\
\hline $\mathrm{Pb}$ & $20-132$ & 48,24 & 29,67 & acceptable & acceptable \\
\hline $\mathrm{Zn}$ & $7-318,7$ & 100,33 & 49,16 & acceptable & acceptable \\
\hline
\end{tabular}

A multivariate statistical analysis (Infostat Program) was performed, achieving identify samples with similar characteristics, classifying them in homogeneous groups as possible, by clusters situations divided into two groups according to structured content of heavy metals. With respect to multivariate cluster analysis, a split occurred in two groups, Group 1 has higher metal contents than group 2. 
For a better understanding of the individual values of the heavy metals to each situation, principal component analysis can be seen in Fig. 2.

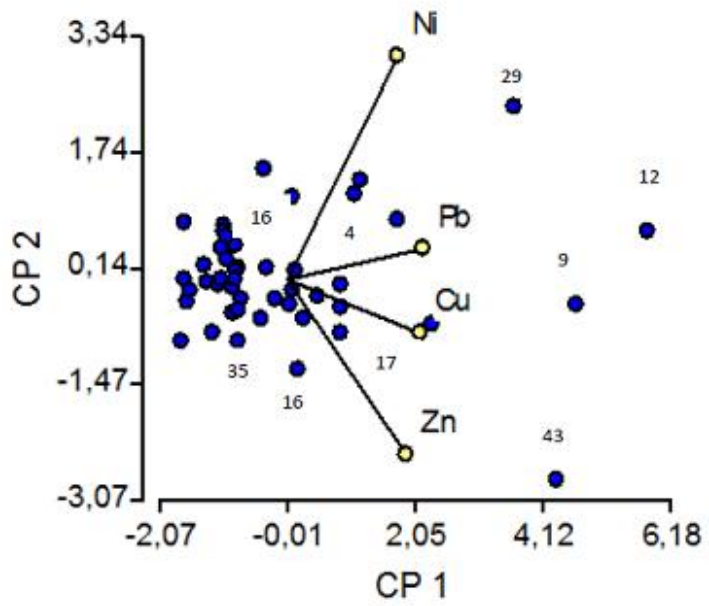

Figure 2: Principal component analysis of the studied samples

This bi-plot derived from principal component analysis, shows the association between the squares and the content of heavy metals. In this way the samples shown in the figure closer to the heavy metals, indicate higher values of the corresponding metals found in these soils. The principal component analysis allowed us to analyze the interdependence between metals, in order to find a graphic representation of the variability of the results, where a clear separation of $\mathrm{Ni}$ and the other metals was shown. This analysis served as a guide for tracking the samples that contained more critical metals, so as to ensure no risks to the population. Metals that showed higher concentration values were $\mathrm{Zn}$ and $\mathrm{Pb}$. Referring to $\mathrm{Zn}$, their study has mainly focused on deficiencies in humans, as it is generally considered non- toxic, but Fosmire (1990) has warned of signs of toxicity at very high intakes of $\mathrm{Zn}$. With respect to $\mathrm{Pb}$, surface natural values are generally less than $50 \mu \mathrm{g} \mathrm{kg}-1$ of soil, so Reagan \& Silbergeld (1989) have proposed a standard of less than $100 \mu \mathrm{g} \mathrm{Pb} \mathrm{g}^{-1}$ soil limited to urban residential areas , to protect children from the habit of "pica" (eating soil).

Soil samples 4, 9, 12, 16 and 29 were closely associated with $\mathrm{Pb}$ and samples 17, 35 and 43 showed a strong relationship with $\mathrm{Zn}$. As those elements presented the greatest values in soils, these samples should be considered as a guide for monitoring samples at successive times to ensure that there is no risk for the population.It is very important to take into account the soil conditions of urban and peri-urban green spaces. Public space is a meeting and reunion point, and is a symbol of city converge, democracy and politics. In addition, parks, gardens and urban orchards guarantee much of the biodiversity in cities (Rueda, 2012). The new global Sustainable Development Goals (UN, 2015) include references to sustainability in cities. Goal 11 states: "Make cities and human settlements inclusive, safe, resilient and sustainable. We recognize that sustainable urban development and management are crucial to the quality of life of our people. Goal 11.3 proposes: "By 2030, enhance inclusive and sustainable urbanization and capacity for participatory, integrated, and sustainable human settlement planning and management in all countries". Urban Environmental Plan of Buenos Aires (article 9) establishes the protection, regulation and control of levels of environmental and landscape quality of public space, through various actions, and related to this study includes the articulation of interventions in public space in relation to situations of risk and environmental quality of the city. Considering what was stated in the Urban Environmental Plan, Article 4, paragraph 4, on "Healthy City" the living conditions should ensure environmental quality and sustainability, so it should be important to repeat the monitoring of heavy metals over time in samples from places that had higher metal contents (samples associated with different metals in the right part of the bi-plot) to ensure that there is no risk for the population.

\section{Conclusions}

Soil quality related to general conditions of fertility of the studied squares was good. The average and maximum content of heavy metals $\mathrm{Cd}, \mathrm{Cr}, \mathrm{Cu}, \mathrm{Ni}, \mathrm{Pb}$ and $\mathrm{Zn}$ in soils of urban green spaces, resulted acceptable values for argentine legislation(Ley $\mathrm{N}^{\circ}$ 24.051/91- Decreto 831/93), indicating the possibility of their use for recreation of the population in these green spaces. The metals $\mathrm{Zn}$ and $\mathrm{Pb}$ were those with higher levels in the studied soils, and samples with maximum values should be monitored at successive times to ensure that there is no risk for the population. 


\section{Acknowledgements}

\section{References}

[1] M. Alberti, Advances in Urban Ecology.Integrating Humans and Ecological Processes in Urban Ecosystems (Springer Science, 2008, ISBN 978-0-387-75510-6).

[2] S. Haq, Urban Green Spaces and an Integrative Approach to Sustainable Environment, Journal of Environmental Protection, 2(5), 2011, 601-608. DOI: 10.4236/jep.2011.25069.

[3] C. Bini and J. Bech, PHEs, Environment and Human Health. (Springer Scienc, 2014. DOI 10.1007/978-94-017-8965-3).

[4] Comisión Europea, Cómo crear un mundo de ciudades sustentables: Investigación sobre desarrollo urbano y uso del suelo sustentables - ONU-HABITAT y UE. (Luxemburgo: Oficina de Publicaciones Oficiales de las Comunidades Europeas, 2004, ISBN 92-894-7703-2).

[5] P.J. Craul, 1992. Urban Soil in Landscape Design (John Wiley \& Sons, Inc., 1992)

[6] A.de Santiago-Martín, I. Valverde-Asenjo, J. Pérez-Esteban, C. Vaquero-Perea, A. Moliner-Aramendía, C. González-Huecas. 2015. Metal contamination in soils in the Mediterranean area and implications for the food chain in R.R Watson, J.A. Tabor, J.E. Ehiri and V.R. Preedy (Ed), Handbook of public health in natural disasters, 2015, DOI: http://dx.doi.org/10.3920/978-90-8686-8063_27, 463-486).

[7] G.J. Fosmire, Zinc toxicity, Am J Clin Nutr, 51 (2), 1990, 225-227.

[8] M Gambuzzi, Espacios urbanos contemporáneos y sus huellas en el Territorio (2012, https://www. estrucplan.com. ar/secciones/articulos/ verarticulo.asp?IDArticulo=2997).

[9] M. Gambuzzi, Espacios urbanos contemporáneos.. ó ¿Sustentables? (2009, http://www.estrucplan .com.ar/secciones/ articulos/ verarticulo .asp?IDArticulo=2050).

[10] J. N. Georgi and D. Dimitriou,The contribution of urban green spaces to the improvement of environment in cities: Case study of Chania, Greece. Building and Environment 45 (6), 2010, 1401-1414.

[11] R. Herrera Vegas, Las claves para crear ciudades sustentables (2010, http://www.lanacion.com.ar/1256340-las-claves-para-crearciudades-sustentables).

[12] Institute for Advanced Sustainability Studies-IASS, Soil contamination a severe risk for the environment and human health, (Global Soil Forum, 2013, http://globalsoilweek.org/wp-content/uploads/2014/11/GSW_factsheet_Contamination_en.pdf.)

[13] Institute for Advanced Sustainability Studies-IASS, Soil sealing. Global Soil Forum, 2014, http://globalsoilweek.org/wpcontent/uploads/2014/11/GSW_factsheet_Sealing_en.pdf).

[14] InfoStat, versión 1.1. (Grupo InfoStat, FCA, Universidad Nacional de Córdoba. Primera Edición, Editorial Brujas, Argentina, 2002.).

[15] Ley 24051, Residuos peligrosos. Decreto reglamentario 831/93. (1992, http://www.infoleg.gov.ar/).

[16] S.McGrath and C.Cunliffe, 1985. A simplified method for the extraction of the metals $\mathrm{Fe}, \mathrm{Zn}, \mathrm{Cu}, \mathrm{Ni}, \mathrm{Cd}, \mathrm{Pb}, \mathrm{Cr}, \mathrm{Co}$ and $\mathrm{Mn}$ from soils and sewage sludges, Journal of the Science of Food and Agriculture, 36, 1985, 794-798.

[17] H .Meuser, Contaminated Urban Soils (Springer Science, 2010, ISBN 978-90-481-9328-8).

[18] A.L. Page (Ed.) Methods of soil Analysis. Part 2. Chemical and microbiological properties. (2 ${ }^{\text {nd }}$ Edition, Madison, Wisc. USA, American Society of Agronomy (Agronomy Series no. 9, 1982).

[19] H. Petrelli, 2009. Planes de las ciudades. Ordenamiento territorial y ordenamiento ambiental. Un análisis crítico de la legislación argentina, Café de las ciudades 8(3), 2009, http://www.cafedelasciudades.com.ar/planes_83.htm).

[20] PNDU, Política Nacional de Desarrollo Urbano .Ciudades Sustentables y Calidad de Vida, Santiago de Chile, 6 de mayo de 2013. http://www.pnud.cl/prensa/noticias-2013/08-05-2013/PolíticaNacionaldeDesarrolloUrbano.

[21] R.V.Pouyat, I.D. Yesilonis and D.J. Nowak, Carbon storage by urban soils in the United States, Journal of Environmental Quality 35, 2006, 1566-1575.

[22] R.V.Pouyat, I.D.Yesilonis, J.Russell-Anelli and N.K. Neerchal, Soil Chemical and Physical Properties That Differentiate Urban Land-Use and Cover Types, Soil Sci. Soc. AmJ. 71, 2007, 1010-1019.

[23] Plan Urbano Ambiental CABA(2008, http://www.cedom.gov.ar/es/legislacion//ley2930).

[24] P.L.Reagan and E.K.Silbergeld, Establishing a health based standard for lead in residential soils, in Hemphill and Cothern (Ed), Trace substances in environmental health (Environmental Geochemistry and Health, Supplement to Volume 12 (1990), 1989).

[25] Real Decreto Legislativo N²/2008. España. http://www.boe.es/boe/dias/2008/06/26/pdfs/A28482-28504.pdf

[26] S. Rueda, El urbanismo ecologico. Territorio, Urbanismo, Sostenibilidad, Paisaje, Diseño urbano (2012, http://www. urbane.aq.upm.es/pdf/).

[27] J.M. Scheyer, 2000. Estimating Dietary Risk from Soils in Urban Gardens, in W.Burghardt and C. Dornauf (Ed), Proceedings of the First International Conference on Soils of Urban, Industrial, Traffic, and Mining Areas (Essen, Germany, July 12-19, 2000, 479-484).

[28] M. Stroganova and T. Prokofieva, 2000. Urban soils concept, definitions, classification. Proceedings of First International Conference SUITMA, (Essen, Germany Vol.1, 2000, 235-241).

[29] United Nations, Transforming our world: the 2030 Agenda for Sustainable Development. ( (2015,http:// sustainabledevelopment.un. org/content/documents/21252030\%20Agenda\%20for\%20Sustainable\%20Development\%20web.pdf).

[30] M.Werkenthin, B. Kluge and G. Wessolek. 2014. Metals in European roadside soils and soil solution - A review, Environmental Pollution 189, 2014, 98-110.

[31] World reference base for soil resource- WRB, A framework for international classification,correlation and communication, World Soil Resources Reports 103, 2006. 